\title{
Factors Affecting Secondary School Teachers' Job Satisfaction in Lushoto District, Tanga Region in Tanzania
}

\author{
Tumaini J. Mbonea*, Akech Eric, Ogega Ounga, Cosmas Nyarusanda \\ University of Arusha Tz, (E.A), Arusha, Tanzania \\ Email: ^tumainimbonea@yahoo.com
}

How to cite this paper: Mbonea, T. J., Eric, A., Ounga, O., \& Nyarusanda, C. (2021). Factors Affecting Secondary School Teachers' Job Satisfaction in Lushoto District, Tanga Region in Tanzania. Open Journal of Social Sciences, 9, 474-490.

https://doi.org/10.4236/jss.2021.96032

Received: May 13, 2021

Accepted: June 27, 2021

Published: June 30, 2021

Copyright $\odot 2021$ by author(s) and Scientific Research Publishing Inc. This work is licensed under the Creative Commons Attribution International License (CC BY 4.0).

http://creativecommons.org/licenses/by/4.0/

\begin{abstract}
The main purpose of this study was to investigate factors affecting job satisfaction level for secondary school teachers in Lushoto District, Tanga region, in Tanzania. The research design applied was survey. Purposive sampling technique was adopted in finding secondary schools and teachers that present all secondary schools in the region. 119 teachers (respondents) were surveyed from both private secondary schools and public secondary schools. Satisfaction or dissatisfaction among categories (groups) of secondary school teachers was calculated in term of means, while then ANOVA test was applied to find job satisfaction difference among categories of secondary school teachers. Research findings revealed that Secondary school teachers were affected by job satisfaction factors which are: pay, social simulation, opportunity for promotion, job condition and job security. Finally by means of ANOVA test with the alpha 0.428 greater than 0.01 and 0.05 it revealed also that there is no significant difference in job satisfaction level among, art department teachers, science department teachers and other department teachers. According to such results the researcher therefore recommends that for raising job satisfaction level for secondary school teachers in all affected areas, for effectiveness and efficiency in the workplace as to have positive academic performance of the students (boosting student's academic performance), the policy should be formulated to make adjustment on the following: 1) Secondary school teachers should be paid and given their returns in regard with time value of money and without delay, given enough time for social simulation (to meet their family, friends, shopping, etc.), promoted equally without delay, to offer good job condition, for example, housing and transport for teachers should be of importance and educational leaders (administrators) should use no kind of threat to their subordinators. 2) Science secondary school teachers, art secondary school teachers and other secondary school teachers in other depart-
\end{abstract}


ments should be recognized, appreciated and given priority equally.

\section{Keywords}

Job Satisfaction, Job Security, Social Simulation, Promotion, Recognition \& Appreciation

\section{Introduction}

The research and the whole process were based on the fact that most of the teachers especially secondary school teachers face many job related challenges which to them act as dissatisfiers to fulfill their duties as oriented to them. To such extent the dissatisfied teachers would lead to ineffective teaching which then may result in students' poor academic performance. The areas of job satisfaction (factors) chosen were: pay, job security, social simulation, opportunity for promotion, recognition and appreciation, interpersonal relation, opportunity to use one's ability, working hour and job condition, opportunity working environment and adequate authority of control. Data collection and analysis had done from the vulnerable of which most students perform poorly based on the history and background. To show the dissatisfaction of teachers in Tanzania there has been existence of secondary school teachers strike and claims to government of not responding to their claim at the right time and accordingly, e.g. Davidson (2007) conducted a survey on teacher motivation in Tanzania and he found that most teachers were unhappy with their pay, fringe benefits, teachers' accommodation, their promotion position, status and number of lessons allocated. This implies that they had a low level of job satisfaction which may result in their poor performance, hence affecting students' academic performance. For instance the performance of form four secondary school student leavers was poor as follows: Division 1-IV in 2011 (53.59\%) was lowered by 1.07. The overall quality of passes has dropped by $1.61 \%$ from 2010 to 2011 (NECTA, 2014).

Michael et al. (1999) state that "Satisfied employee tends to be more productive, creative and committed to their employers." Poor performance of many secondary school students especially from four livers in Tanzania existing today may be contributed mostly by dissatisfaction of teachers. In the same case failure of secondary school students in Lushoto district, may be contributed much more by dissatisfaction of teachers. Since dissatisfaction of teachers tends to make them unproductive, uncreative and uncommitted to the job "Factors associated with job satisfaction are different from those linked to dissatisfaction" (Hertzberg, 1966).

Hertzberg et al. (1959) state that dissatisfaction relates primarily to external or extrinsic aspects of a job. According to him, inadequate job Security, salary and fringe benefits, working conditions job status, quality of supervision and relationship with coworkers and supervisors are key factors for job satisfaction.

The important factors in satisfaction include being given individual responsi- 
bility, having opportunity for advancement, and doing work that is challenging, allow one to demonstrate unusual degrees of achievement, and foster personal presence. According to Latham and Marshall (2006); Steer and Porter (1975) - one key component of jobs that are satisfying is to allow people to set and achieve clear goals. Zembylas and Papanastasious (2006), who studied teacher job satisfaction and dissatisfaction, suggest that, "there is an urgent need for policy makers to recognize the fact that educational quality is largely related to teacher job satisfaction." This implies that teacher's job satisfaction is an important aspect for a country like Tanzania which is trying to fight ignorance among its citizens both quantitatively and qualitatively. If teachers are not satisfied, may remain as agitators, mourners, reluctant or resistant to school, project, programs or plans planned for the best of school. There is poor performance of many Secondary school students' especial Form Four leavers in Tanzania, especially in Lushoto district.

Poor performance of Secondary School students may be led by low level of satisfaction of teachers which in turn may be caused by poor education management. Parents identify number and motivation of teachers as the main bottlenecks. According to Lilian (2014) "Private secondary schools teachers in Tanzania were more satisfied and motivated than those of Public secondary schools. Most teachers were dissatisfied with lack of promotional opportunities, poor supervision, lack of organizational policies, undefined nature of jobs and poor organizational communication" networks.

Retionale of this study is to come up with the solution for job related problems which affect secondary school professionals for them to work (teach) effectively and efficiently inoder to raise sdudents academic performance for national development. In the sense that it will contribute to good and effective educational practices within Tanzania. It will also contribute to knowledge and be the guideline in developing the theory which would eventually serve as a perquisite to job satisfaction in all sectors of secondary education in deliverance of quality education to the benefit of teachers and students as well as educational administrators within Lushoto district, Tanga region, Tanzania and the world over.

Moreover, stakeholders and educationists who are the policy makers may use the study to formulate and implement educational policies that could promote job satisfaction, foster a better employee-employer relationship with regard to educational administration.

\section{Literature Review}

\subsection{Types of School Job Satisfaction Related}

There are several studies conducted on job satisfaction and on the factors that affect job satisfaction for workers who are teachers especially secondary school teachers global wise and local wise. For instance a study that was conducted on job satisfaction for teachers in the United Kingdom indicated that teachers who worked in independent and private schools in the United Kingdom showed to 
have higher levels of job satisfaction than their colleagues in other types of schools (Crossman \& Harris, 2006). However, other research findings indicate that teachers in public and private schools did not differ in the job satisfaction levels significantly (Zhang, 2008). For these findings and their variation, it is obvious therefore that teachers' job satisfaction depends on type of school but rather depends on the areas of job satisfaction factors they are satisfied by the administration. For instance, the study conducted by Dinham and Scott (2000), found that teachers who had earned promotions in their schools were more satisfied with their job than unpromoted ones. The investigation done by Eric (2015) revealed that "Teachers in Tanzania were dissatisfied with salary, promotion opportunity, fringe benefit, work load, job security and stability”.

\subsection{Interpersonal Relation as Satisfaction Factors}

As for other study it was found that workers job satisfaction is derived from collegial relationship that they enjoy at their work place (Dessler, 2005). This interpersonal relation was seen therefore to be among the factors that affect job satisfaction for workers including secondary school teachers. Another job satisfaction factor (salary) was studied by Shafritz et al. (2005) who argues that salary is the main demand which a worker is making of his employment and that what an employee wants is simply to be assigned work that he or she is supposed to do and the amount of money they will earn by the end of the day for such a job and nothing else. This implies that money is the main source of satisfaction to some employees.

Robbins and Judge (2008) assert that employees derive their job satisfaction from such facets as: the job itself, salary, possibilities to advance themselves, supervision and relationship with their workmates.

Oshagbemi (1997) in his study on job satisfaction among university lecturers and professors in the United Kingdom employed a modified Job Descriptive Index which included eight aspects and these include: "1) teaching; 2) research; 3) administrative and managerial duties; 4) present pay; 5) opportunities for promotion; 6) supervision/supervisor; 7) co-workers; 8) physical conditions/working facilities" (Oshagbemi, 1997). This implies that previous researchers do not concur on the facets of job satisfaction though some of the facets are similar.

\subsection{Recognition and Appreciation as a Satisfaction Factor}

Duodu (2001) on human relations theory affirms that the attention paid to workers and their involvement in activities of the organization could bring about increased productivity on the role of educational administrators. Mordedzi states that, educational administrators are managers of educational institutions who need good management techniques to carry out their tasks, encourage harmony and ensure effective performance.

Agyeman (2008) says the importance of the teacher-learner relationship in the classroom lies in the fact that it has a direct bearing on the personality develop- 
ment and achievement of the leaner. Another area where students contribute greatly to teacher job satisfaction is the response teachers get from students' performance with regards to assignments and class contributions. Mankoe (2002) also identified that the use of student committees and the suggestion boxes promotes a healthy staff-student relationship.

\subsection{Interpersonal Relationship and School Type as Satisfaction Factor}

For effective teaching and learning to take place in any educational institution, there is the need to develop good interpersonal relationship, i.e. good relationship with the heads, teaching staff, non-teaching staff, parents and the students' relationship should be of more importance. As posited by Dessler (2005) interpersonal relationship should be the teaching and non-teaching staff, teachers and students and non-teaching staff and student. For this kind of relationship it plays a crucial role in teachers' job satisfaction. As for research conducted by Boniface (2016) "Teachers in Tanzania perceived problems related to housing, social services, conflicts in schools the teaching and learning situations and limited opportunities."

\subsection{Working Environment as a Satisfaction Factor}

Working environment in school termed as school climate or school atmosphere is one of the most important determinants of a prevailing and consequent relationship among staff and leaders of the school is the school. The head of the school may not determine the school atmosphere yet, his unapproved leadership style may have some negative effects on the climate. Where people (teachers) work under able leader, they become happy and consequently give out their best. Asiedu-Akrofi (1978) identifies six major types of organizational climate which are: 1) a situation where members of staff are aware of what goes on in the school is what is classified as open climate. 2) The controlled climate is a school climate in which the head teacher's concern is all about school achievement. All activities are directed towards attainment of goals. Teachers cooperate well in such circumstances, but do not feel happy. 3) Explaining the paternal climate, he described the head of the school as a person who is on the average older than the teachers. Teachers in this type of climate are free to do whatever satisfies them but cannot influence the head teacher's decision. 4) To him another climate is the closed type. In this type of school climate, teachers are not involved in decision making hence they tend to be apathetic Consequently, indiscipline gains ground both among teachers and students since none of the staff is prepared to cooperate with the head in the administration of the school. 5) The fifth aspect of the school climate is the autonomous climate which is based on consensus of staff, students and the head of the school. Group leadership plays prominent role in causing things to happen and it could be linked to the open climate. 6) The familiar climate. 7) The head of the school is indifferent to the main purpose of 
the school; as a result, teachers do not see the need for sustaining set goals. In this type of climate, parents and students suffer as they become losers. Douglas (2000) conducted a research which revealed that teachers generally have position perceptions about the District, their colleagues and the work environment. Virginia et al. (2005) asserts that positive educational environment prevails in countries where children go to school in well-equipped buildings, have 900 hours of learning time per year, 52 Odon capital material inputs, a curriculum that is carefully planned, a teacher with 16 years of education and pupils teacher ratio of 20:1. Comparatively, he assessed classroom conditions in developing countries as generally poor, inadequate or poorly maintained facilities with instructional materials in short supply.

\subsection{Pay as Satisfaction Factor}

However, the teachers expressed low satisfaction with respect to factors such as remuneration and benefits and opportunities for professional development. Schaefer (2005) says high wages give workers a sense of accomplishment apart from the task before them. This assertion may vary according to the type of job satisfaction investigate. For instance, a teacher in either public or private secondary school with higher wages may still be dissatisfied when he spends several hours at work to the neglect of his health and family needs.

\subsection{Use of One's Ability as Satisfaction Factor}

Several factors that may contribute to the job satisfaction among employees may be economic, social prestige recognition, emotional satisfaction, psychological or any form of reward by employers. Schaefer (2005) asserts that, people of greater responsibility for finished product such as white-collar job professionals and managers experience more satisfaction than those with less responsibility. This is affirmed by the fact that both women and men working in blue collar-job with repetitive nature of work can be particularly unsatisfied. Gibson (1991) believes that job satisfaction is the attitudes that workers have about their work as a result of their perception of the work. From this perception it could be said that workers' attitudes could be influenced by the environment. These may be the style of supervision, workplace policies and their implementation, group or union affiliations, fringe benefits and the condition of service.

\subsection{Job Security as Satisfaction Factor}

It is obvious that when employees feel unhappy or not the part and parcel of organization Inco operate the fear of dismissal from job. According to Mankoe (2002) the three salient basis upon which morale of organizational workers thrive are: The extent to which organizational goals and individual needs are met. The compatibility of bureaucratic expectations and personal needs (sense of belonging), rational, logical and bureaucratic organizational goals (sense of rationality). 


\subsection{Working Hours as Satisfaction Factor}

Duodu (2001) proposed that the administrator performs executive duties and works with human beings to achieve set goals within a set framework of time. He further asserts that, school administrators spend a considerable amount of time working with various groups in different settings. To his statement various groups that are teachers spend amount of time to fulfill their on work day to day duties, i.e. too long working hours without considerable pay may disappoint them.

\subsection{Teachers' Job Dissatisfaction Based Factor}

Albanese (2008) points out that, job dissatisfaction associates with: monthly salaries, incapable and nonsupport administrators and lack of collegian relationship with co-workers. According to him incapable leaders and salary were key factors that influenced job dissatisfaction. This implies that teacher's job dissatisfaction is associated with leader's incapability. The study done by Nyamubi (2017) found that "Teachers were satisfied by both monetary and non-monetary incentives such as community support. They were pleased with fair remuneration packages that related to their labor input, opportunity for career development, a well defined individual appraisal system, time promotion and requisite workplace conditions. Teachers showed that friendship and cooperation with workers and students as well as the respect of community members also enhanced satisfaction in teaching". The results of the research conducted by Msuya (2016) showed that "Job satisfaction in Tanzania was not homogenous: social economic and demographic factors had a great contribution on varying job satisfaction levels".

According to Eutimi (2018) "There was a significant difference in financial motivation between public and private secondary school teachers in Kigoma District in Tanzania”.

\subsection{Impacts of Teachers' Job Satisfaction}

Judge et al. (2008) concluded that, job satisfaction results in teacher's performance, job turnover, absenteeism and involvement in teacher's union activities. Though, there is no empirical data that justifies direct or indirect influence of employee's satisfaction on productivity. Latham (1998: p. 83), posited that "job satisfaction can do far more than help retain teachers; it can improve their teaching". This implies that satisfied teachers can contribute significantly to the improvement students' academic performance and school effectiveness at large. Similarly, Shann (2001) asserts that job satisfaction helps to retain teachers and makes them committed to their job and through this also makes their schools very effective. In other words, job satisfaction contributes to improvement of teaching, students learning and teacher retention.

Travers and Cooper (1996) claim that low satisfaction with salary and the lack of promotion opportunities contributed significantly to teacher's intention to 
quit the job. This implies that high satisfaction with these variables would contribute to their intention to remain in the job. Through, recent survey conducted in United States of America revealed that employees do not remain in their jobs because of good salaries and fringe benefits, but they stay because of the collegial relationship with co-workers and managers.

A research conducted by Syepwa (2015) showed that "Teachers in Tanzania worked under difficult condition due to inadequate number of physical infrastructure and shortage of teaching and learning facilities".

Nnadi (1997) claims that job satisfaction is composed of the reaction, attitude or perception of the individual to work. These are what the work should be. The employee is concerned about the content and the context as well as the end result. He is satisfied if he believes what the job is value, and may become disillusioned and dissatisfied when he finds that the job is below his expectations.

Bootzin, et al. (1986) in affirming the state of a satisfied worker made it clear that, common sense holds that a happy worker is a productive worker. In support of Bootzin et al. Mcshane and von Glinow (2000) say job satisfaction represents a person's evaluation of his or her job and work context. Job condition and the environment in which job takes place also contribute immensely to job satisfaction. Hellriegel et al. (1998) posit that it is the feelings about various aspects of the worker's job setting and worker's expression of happiness could vary as regards to job satisfaction.

Factors identified are economic rewards, social rewards, company policy and its implementation or administration (Nnadi, 1997). The rest are interpersonal relationships, working conditions, achievements, recognition, work itself and advancement. From the few constituents of job satisfaction so far identified, it would be quite obvious for any employer to meet all these demands at focus. So could it be that which of these conditions make the employee satisfied would be very difficult to determine. It is however not surprising when the organizational psychologists postulate that the modest association between job satisfaction and task performance is that, general attitude does not predict specific behavior very well. Kreitner and Kinicky (2001) identified that job satisfaction is not a unitary concept. Rather, a person can be relatively satisfied with one aspect of this job and be dissatisfied with one or more other aspects.

Job satisfaction is one measure of the equality of life in the organizations, then, this measure needs to be defined as to what level the teacher and other employees could accept (Schaefer, 2005). Schaefer however, did not see how a segment of the need could be satisfied without others. He therefore claims that, "Job satisfaction may vary directly with the extent to which those needs of the individuals which can be satisfied are actually satisfied" (Schaefer, 2005). Satisfaction is however defined as "the good feeling that you have when you have achieved something a need or desire" Schaefer (2005).

In a related research, Bame (1991) identified commitment to work as a variable of job satisfaction and said the degree to which a person is identified psychologically with his work or the importance of work in his total self-image. 
Peretomode (1992) posits that job satisfaction is a concept which is closely related to motivation. This makes many people think that motivated employees are synonymous to satisfied employees. Mullins (2007) affirms this by saying that "motivation is the driving force within individuals by which they attempt to achieve some goal in order to fulfill some need or occupation". For example, psychologists are of the view that many different motives such as needs for order, understanding and economic independence guide behavior.

Mullins (2007) states that, "motivation (satisfaction) is based on values rather than financial reward". Adequately remunerated worker is motivated both intrinsically and extrinsically. The intrinsic motivation and satisfaction derived from successful completion of a task makes the worker find similar and improved means to approach a given task under a similar prevailing working environment. Since intrinsic motivation is limited to personal experience, McClelland's concept of motivation is therefore linked to Hertzberg's motivation hygiene theory that people with high achievement motivation tend to be interested in the motivators (the job itself). Motivation and job satisfaction may appear to be synonymous; however, research has shown that they are two different things. Gibson et al. (1976) identified that the two terms are related but not synonymous. They see satisfaction as one variable or a constituent of motivation. To them motivation primarily is a goal directed behavior while job satisfaction refers to fulfillment required by experiencing various job activities and rewards. From this assertion it is possible that a bow level income employee may not feel motivated but would be satisfied with his job. On the other side of the coin, a highly motivated employee may turn to be dissatisfied with every aspect of this job.

\subsection{Job Satisfaction through Administration}

Morale is closely related to job satisfaction as such, leaders hold the key to employees' attitude, job satisfaction and high morale Mankoe (2002). This is supported by Duodu (2001) that the function of organizational leadership is to influence the group toward achievement of group goals, and leadership which rings its strength from the willingness of others to follow, the art of inducing or influencing others to work willingly as an attribute of job satisfaction and morale derived from employees' task performance.

However there is no need to compete too hard or too little, unfairly, or you won't win much cooperation from other supervisors; to attract competitors to your department, create room for workers to upgrade themselves to attain their goals. This also affords you the opportunity to win friend among other supervisors; See to your own business and allow other supervisors to go about their work. This limits the rate of dispute among employees; finally, administrators are to cooperate with their employees to enable employees by their success to promote assistance; a good administrator who cooperates with the staff helps the staff to be satisfied with their task performances hence morale becomes very high. This when done leads to attainment of enduring organization that will 
thrive most efficiently Mankoe (2002) quoted in Ampratwum-Mensah (2009).

According to Lilian (2014) "Private secondary schools teachers in Tanzania were more satisfied and motivated than those of Public secondary schools. Most teachers were dissatisfied with lack of promotional opportunities, poor supervision, lack of organizational policies, undefined nature of jobs and poor organizational communication" networks.

\subsection{Teacher's Job Satisfaction Based Impacts}

Bame (1991) in his study he revealed that teachers' plan to remain or leave teaching, commitment to teaching, and teachers' transmission of value coupled with both negative and positive attitudes about teaching to their pupils and absenteeism cannot be ruled out. He asserted that an alternative to dissatisfied teachers performance is that, dissatisfied teachers who remain in teaching may reduce their performance created by their dissatisfaction. The behavior of dissatisfaction and unwilling to perform better in job place is termed as "citizenship behaviors" Gibson et al. (2000).

\section{Methodology}

\subsection{Research Design}

Research design implied in this research was survey. The type of questionnaire used in this research consisted of a Likert Scale type of questionnaire that asks individuals to check their level of satisfaction with various statements about their job (e.g., 4. Strongly agree, 3. Agree, 2. Disagree, 1. Strongly disagree). Data collection had been done where questionnaire distributed face to face to the respondents in three public secondary schools and two private secondary schools which make the total of 5 Secondary schools out of 38 in Lushoto district.

\subsection{Population}

The research involved 119 teachers out of 720 teachers in both private and public secondary schools within Lushoto District, in Tanga region of Tanzania. Two private secondary schools in Lushoto district council were chosen in addition to other three public secondary schools. These schools were used because they are accessible as well they have the characteristics of other secondary schools within the district/council. Thus, the current study was conducted among teachers from Public and Non-Public (Private) Secondary Schools in Lushoto District which form research population for conducting research on factors affecting job satisfaction for secondary school teachers.

\subsection{Sample and Sampling Procedure}

The purposive technique of sampling was applied in this research. 71 male teachers from public secondary schools and 48 female teachers from private secondary schools in Lushoto District were selected. 63 Male secondary school teachers and 56 female secondary school teachers which make 119 secondary 
school teachers out of 720 were involved in the study. The use of purposive sampling technique is to ensure that teachers who had at least one year experience and above in teaching in the council involved in responding to the questionnaire. Again it was used to prevent heads of the respective schools from participating because aspects of the questionnaire had to do with assessing them, and also to do away with conflict of interest of which heads of schools were to be observed. In this study convenience sample were selected not only because they are easily found but also because do present the characteristics of the whole population of the study.

\subsection{Validity and Reliability of Instrument}

\subsubsection{Validity}

To ensure validity of the instrument the study employed the following techniques: First the study applied outside questionnaire of discrimination validity of 0.80. Spector (1997) consisted of nine job satisfaction factors which are typically related to the research instrument. The questionnaire items from outside sources were then expanded to many items. The validity of the instrument was also ensured through which items originated under the same criteria were jumbled to avoid bias during the responses and to reduce validity-related risks. First, the related literature was reviewed to get the theoretical knowledge about the content or subject and definitions of concepts that are used before designing the instrument for the particular study. Additionally, content validity was implied to test the instrument through presenting it to experts and peers for discussions and comments. This helped to eliminate ambiguities in the items.

\subsubsection{Reliability}

Internal consistency reliability of the instrument obtained through spilt half. External reliability attained by ensuring all procedures of administering questionnaire were followed e.g. good instructions were given to the participants before supplied them with questionnaire.

To obtain good reliability all main variables were prepared for job satisfaction and the survey instrument was presented to peers in the Masters of Educational in Management and Leadership Programme whose majority were secondary schools teachers in their respective councils/District in Tanzania. Supervisors and Professors comments during the research seminars and thereafter adjustments and corrections were made to the instrument before it was administered to the targeted population sample. The Spearman Brown formula was applied to obtain the reliability of 0.93 .

\subsubsection{Instrument}

The questionnaire was divided into two sections. (A) Demographic data, (B) Factors of job satisfaction for secondary school teachers. Under each main item there were minor items which were the aid for reliability. The second part of the questionnaire contained items on which respondents were responded on: pay (return), job security, social simulation, and opportunity for promotion, recog- 
nition and appreciation, interpersonal relation, use of one's ability, working hours and job condition, equal opportunity working environment adequate authority of control. The scale applied was a 4-point Likert type Scale weighed as follows: 1 = Strongly Dissatisfied, 2 = Dissatisfied, 3 = Satisfied, $4=$ Strongly Satisfied. To measure job satisfaction level a rating scale questionnaire is prepared for employees to report their perception reaction to their job.

\subsection{Data Collection Procedure}

Followed an introductory letter from the head of directorate of the post graduate studies faculty of education from the University of Arusha, so to establish the authenticity of the research for data collection from the respondents, the researcher procured another letter of introduction from District Excutive Dirretcor in Lushoto and copies submitted to the heads of the proposed secondary schools expected for data collection. The questionnaire was distributed and administered within five weeks. That was due to the fact that the researcher had to rely on self transport preparation to reach more scattered and remote targeted secondary schools. After the face to face distribution of questionnaire the participants were given enough time to consider/organize their answers to every item that can respond to at the convenient time. This gave them freedom to think thoroughly before they can make responses.

\subsection{Data Analysis}

Data that gathered from respondents was analyzed and presented in form of means to find satisfaction or dissatisfaction of teachers on each factor and ANOVA was applied to find job satisfaction difference among categories of secondary school teachers. Each research question was analyzed based upon the main job factors.

\section{Results and Discussion}

Teacher's job satisfaction may or may not vary in regarding to either public or private school sectors. As for this study results, public secondary school teachers were satisfied on pay Mean $=1.65$, social simulation Mean $=1.92$, working hours and cognition Mean $=1.75$, all these data fall under dissatisfaction according to the scale, Table 1. Private secondary school teachers ranked high in mean job satisfaction followed by public secondary school teachers except in the domain of job security where public secondary school teachers were highly satisfied than private secondary school teachers i.e. public secondary school teachers job satisfaction was Mean $=2.37$ of satisfaction and private secondary school job satisfaction was mean $=1.67$ satisfaction $($ Table 1$)$.

Public secondary school teachers were strongly dissatisfied on opportunity for promotion by Mean $=0.77$ and strongly satisfied on equal opportunity working environment by Mean $=2.92$. Private secondary school teachers were dissatisfied on job security by Mean $=1.67$, opportunity for promotion by Mean $=1.98$ 
Table 1. Job Satisfaction level for secondary school teachers.

\begin{tabular}{ccc}
\hline Factors & Public & Private \\
\hline & & Mean \\
\hline Pay & 1.65 & 2.42 \\
Job security & 2.37 & 1.67 \\
Social simulation & 1.92 & 1.13 \\
Opportunity for promotion & 0.77 & 1.98 \\
Recognition \& Appreciation & 2.04 & 3.54 \\
Interpersonal Relationship & 2.38 & 3.30 \\
To use one's ability & 2.21 & 3.21 \\
Job condition & 1.75 & 2.46 \\
Working environment & 2.92 & 3.40 \\
Authority of control & 2.25 & 3.79 \\
\hline
\end{tabular}

Source: Field work data analysis 2019.

while in other domains of job satisfaction, private secondary school teachers were smoothly satisfied. Both public and private secondary school teachers were satisfied on opportunity for promotion by Mean $=0.77$ and Mean $=1.98$ respectively. In other domains private secondary school teachers were highly satisfied followed by public secondary school teachers.

This means therefore that public secondary school teacher's face challenges on pay, social simulation, working environment and opportunity for promotion i.e. they are not supplied with appropriate returns, they have no ample time to spend with their families or relatives, they are not promoted at the right time. While private secondary school teachers face challenges on job security and opportunity for promotion. This shows therefore that there is regular firing of workers in private secondary schools, as well no promotion for improvement of returns (salaries).

This indicates therefore that secondary school teachers were either satisfied or dissatisfied in this area of opportunity for promotion. As for this results of this research public secondary school teacher's shares job satisfaction level in some aspects with private secondary school teachers. This means that, there is no direct relationship of problems facing public secondary school teachers with those facing private secondary school teachers but they share in some aspects of job satisfaction.

This research reveals therefore that private secondary school teachers were slightly satisfied than public secondary school teachers and both categories of teachers face the same challenges in some domains i.e. there is no significant relationship of job satisfaction level between public secondary school and private secondary schools in Lushoto District Research conducted in the United Kingdom indicated that teachers differed in job satisfaction in relation to the type of school in which they worked (Crossman \& Harris, 2006). The teachers who worked in independent and private schools in the United Kingdom indicated higher levels of job satisfaction than their colleagues in other types of schools. However, other research findings indicate that teachers in public and private 
schools did not differ in the job satisfaction levels significantly (Zhang, 2008).

The difference of job satisfaction/perception for Arts teachers, Science teachers and other departments for secondary school teachers in Lushoto district.

The following were the results used an inferential statistics test namely one way ANOVA in testing the hypothesis such that:

$\mathrm{H}_{0}$ : There are no significant differences among the means of job satisfaction factors for art department teachers, science department teachers and other departments $\left(\mathrm{H}_{0}: \mu_{1}=\mu_{2}=\mu_{3}\right)$.

$\mathrm{H}_{1}$ : There are significant differences among the means of job satisfaction factors for art department teachers, science department teachers and other departments. ( $\mathrm{H}_{1}$ : Means are not all equal). The significance for this test required alpha to be between 0.05 and 0.01 .

From Table 2 analysis we observe that $p$-value is greater that the a value-that is $0.428 \geq 0.05$, therefore we fail to reject the null hypothesis in this situation there was no need to carry out post hoc test, and we conclude that there are no significant differences among the means of job satisfaction factors for art department teachers, science department teachers and other departments. This research indicates that there is no difference of job satisfaction level between secondary school teachers working in different departments while also other research. e.g. shows that teachers' job satisfaction did not differ significantly in relation to departments they teach i.e. science and Art teachers (Fred, 2009).

According to this research result it is obvious therefore that secondary school teachers in all departments face the same administration challenges which in one way or another result in their performance at job place. There is no need to find out the solutions for a particular category/department of secondary school teachers in comparison to others i.e. any policy formulation to solve secondary school teachers should not discriminate any class of them i.e. science department, art department or other departments.

\section{Findings}

\section{Q.1. What are the factors affecting job satisfaction level for secondary school teachers in Lushoto District?}

There are factors found affecting job satisfaction for secondary school such that: Public secondary school teachers were dissatisfied on, pay, social simulation, opportunity for promotion, and job condition. While private secondary school teachers were dissatisfied on, job security and opportunity for promotion.

Table 2. Job satisfaction difference among categories of secondary schools teachers.

\begin{tabular}{cccccc} 
& Sum of Squares & $\mathrm{df}$ & Mean Square & F & Sig. \\
\hline Between Groups & 0.209 & 2 & 0.104 & 0.855 & 0.428 \\
Within Groups & 13.689 & 112 & 0.122 & & \\
Total & 13.689 & 114 & & & \\
\hline
\end{tabular}

Source: Field work data analysis 2019. 
Q.2. Is there difference in job satisfaction among science teachers, art teachers and other department teachers?

By using ANOVA test it was found that there is no difference in job satisfaction level between secondary school teachers working in different departments with, $p$-value is greater that the $\alpha$ value-that is $0.428 \geq 0.05$.

\section{Conclusion and Recommendation}

\subsection{Conclusion}

According to the research results it is concluded here that public secondary school teachers did not receive their salary accordingly, were not given time for social simulation, were not promoted at the right time and were not supplied with fair working conditions. While private secondary school teachers were not recognized as part and parcel of the institution or they are dismissed from job regularly.

It is also according to this research result concluded therefore that secondary school teachers in all departments face the related administration challenges which in one way or another which may result in their performance at job place.

\subsection{Recommendations}

With such conclusion the researcher therefore recommends here that for raising job satisfaction level for secondary school teachers in all affected areas, for effectiveness and efficiency in the workplace as to have positive academic performance of the students (boosting student's academic performance), the policy should be formulated to make adjustment on the following:

1) Secondary school teachers should be paid and given their returns in regard with time value of money and without delay, given enough time for social simulation (to meet their family, friends, shopping etc.), promoted equally without delay, to offer good job condition, for example, housing and transport for teachers should be of importance and educational leaders (administrators) should use no any kind of threat to their subordinators.

2) Science secondary school teachers, art secondary school teachers and other secondary school teachers in other departments should be recognized, appreciated and given priority equally.

\section{Conflicts of Interest}

The authors declare no conflicts of interest regarding the publication of this paper.

\section{References}

Agyeman, D. K. (2008). Sociology of Education for African Students. Accra: Black Mask Ltd.

Albanese, A. R. (2008). Take This Job and Love It. Library Journal, 133, 36-39.

Ampratwum-Mensah, A. (2009). Public Urged to Motivate Teachers Daily Graphic (No. 
150203) (p. 21).

Asiedu-Akrofi, K. (1978). School Organization in Modern Africa. Tema: Ghana Publishing Corporation.

Bame, N. K. (1991). Teacher Motivation and Retention in Ghana. Accra: University Press.

Boniface, R. (2016). Teachers' Retention in Tanzania Secondary Schools. Småland:' Linnaeus University.

Bootzin, R. R. et al. (1986). Psychology Today: An Introduction (6th ed.). New York: McGraw-Hill Publishing Company.

Crossman, A., \& Harris, P. (2006). Job Satisfaction of Secondary School Teachers. Educational Management and Leadership, 34, 29-46.

https://doi.org/10.1177/1741143206059538

Davidson, E. (2007). The Pivotal Role of Teacher Motivation in Tanzanian Education. The Educational Forum, 71, 157-166. https://doi.org/10.1080/00131720708984928

Dessler, G. (2005). Human Resource Management. London: Pearson Education Inc.

Dinham, S., \& Scott, C. (2000). Moving into the Third Outer Domain of Teacher Satisfaction. Journal of Education Administration, 38, 379-396.

https://doi.org/10.1108/09578230010373633

Douglas, D. T. (2000). Teacher Job Satisfaction Survey. New York: A. Holt Rinehart and Winston Inc.

Duodu, F. W. K. (2001). The School Administrator. Kumasi: SOSFAC (Gh.) Ltd.

Eric (2015). Factors Influencing Job Satisfaction among Secondary School Teachers in Tanzania; Case Study of Kongwa District. Masters Dissertation, Morogoro: University of Morogoro.

Eutimi (2018). The Influential Motivational to Teachers Job Satisfaction in Secondary Schools in Kigoma District. Dar es Salaam: Open University of Tanzania.

Fred, W. G. (2009). Job Satisfaction among Secondary School Teachers in Tanzania. Jyväskylän, Finland: University of Jyvaskya.

Gibson, G. (1991). The Expectations and Master Pieces. SAGE Journals.

Gibson, J. L. et al. (1976). Organization Behaviour and Structure Process. Boston, MA: Irwin Inc.

Gibson, J. L., Ivancevich, J. M., \& Donnelly, J. H. (2000). Organizations. New York: McGraw Hill Companies Inc.

Hellriege, D., Slocum, J. W., \& Woodman, R. W. (1998). Organizational Behaviour (8th ed.). New York: South-Western Publications.

Hertzberg, F. et al. (1959). The Motivational to Work. New York: Wiley.

Hertzberg, F., Mausner, B., \& Synderman, B. (1966). The Motivation to Work (2nd ed.). New York: John-Willey and Sons.

Kreitner, R., \& Kinicki, A. (2001). Organizational Behaviour. New York: Irwin/McGraw Hill.

Latham, A. (1998). Teacher Satisfaction (pp. 82-83). Alexandria: Association of Supervision and Curriculum Development.

Latham, G. P., \& Marshall, H. A. (2006). The Effects of Self-Set, Partipacively Set and Assigned Goals on the Performance of Government Employees. Personnel Psychology, 35, 399-404. https://doi.org/10.1111/j.1744-6570.1982.tb02204.x

Lilian (2014). Assessment of Job Motivation and Job Satisfaction among Secondary School Teachers in Tanzania-Case Study in Kinondoni Municipality. Masters Disser- 
tation, Morogoro: Mzumbe University.

Mankoe, J. O. (2002). Educational Administration and Management in Ghana. Accra: Progressive Star Printing Press.

McShane, S. L., \& Von Gluons, J. (2000). Organizational Behaviour. Boston, MA: McGraw Hill Company Inc.

Michael, J. et al. (1999). Job Satisfaction: Putting Theory into Practice. Family Practice Management, 6, 26-30.

Msuya (2016). Exploring Level of Job Satisfaction among Teachers in Public Secondary School Teachers in Tanzania. Dodoma: University of Dodoma.

Mullins, L. J. (2007). Management and Organizational Behaviour (8th ed.). London: Pearson Education Ltd.

NECTA (2014). National Results Statistics for form Four Students. Dar es Salaam: Ministry of Education and Vocational Training, DSM Tanzania.

Nnadi, E. E. (1997). Handbook on Human Resources Management for Health Care Professionals. Washington DC: Howard University Press.

Nyamubi (2017). Determinants of Secondary School Teachers' Job Satisfaction in Tanzania. Education Research International, 2017, Article ID: 7282614. https://doi.org/10.1155/2017/7282614

Oshagbemi, T. (1997). Job Satisfaction and Dissatisfaction in High Education. Education + Training, 39, 354-359. https://doi.org/10.1108/00400919710192395

Peretomode, V. F. (1992). Educational Administration: Applied Concepts and Theoretical Perspectives for Students and Practitioners. Lagos: Joja Educational Research and Publishers Ltd.

Robbins, S. P., \& Judge, T. (2008). Essential of Organizational Behavior (9th ed.). San Diego, CA: San Diego State University.

Schaefer, R. T. (2005). Sociology. Boston, MA: McGraw Hill.

Shafritz, J. M. et al. (2005). Classics of Organization Theory. Belmont, CA: Thomson Wadsworth.

Shann, M. H. (2001). Professional Commitment and Satisfaction among Teachers in Urban Middle Schools. The Journal of Educational Research, 92, 67-73. https://doi.org/10.1080/00220679809597578

Spector, P. E. (1997). Job Satisfaction: Application, Assessment, Causes, and Consequences. Thousand Oaks, CA: Sage Publications. https://doi.org/10.4135/9781452231549

Steer, R. M., \& Porter, L. W. (1975). The Measurement of Organizational Commitment. USA: University of California.

Syepwa, S. (2015). Teachers Working Condition and Their Job Satisfaction: Case Study in Nachingwea District. Masters Dissertation, Dodoma: University of Dodoma.

Travers, C. J., \& Cooper, C. L. (1996). Teachers under Pressure: Stress in the Teaching Profession. London: Routledge.

Virginia, D. S. W. et al. (2005). Focus Group Findings on Job Satisfaction Recommendations for recruitment and Retention Strategies. New York: Fordham University.

Zembylas, M., \& Papanastasiou, E. (2006). Sources of Teacher Job Satisfaction and Dissatisfaction in Cyprus. Compare: A Journal of Comparative and International Education, 36, 229-247. https://doi.org/10.1080/03057920600741289

Zhang, S. S. (2008). Study of Job Satisfaction among Elementary Schools in Shanghai. Chinese Educational Society, 40, 40-46. https://doi.org/10.2753/CED1061-1932400505 